\title{
Impact of intensive maize silage supplementation on milksolids production, mastitis and profit
}

\author{
D.E. DALLEY ${ }^{1}$, S.J. COLLIS ${ }^{1}$ and J.W. CLOUGH ${ }^{2}$ \\ ${ }^{I}$ Dexcel, R.D. 12, Hawera \\ ${ }^{2}$ Wrightson Consulting, P.O. Box 440, Ha wera \\ dawn.dalley@dexcel.co.nz
}

\begin{abstract}
Over four dairy seasons (2000/2001 to 2003/2004) the input of maize sila ge was evaluated at the Waimate West Demonstration Farm. Two systems were evaluated with Jersey cows: Control (3.8 cows/ha, no maize silage) and High stocked (HS) Maize (5 cows/ha, up to 1.5 t dry matter $(\mathrm{DM}) /$ cow $/ \mathrm{yr}$ as maize silage). Both farmlets received $190( \pm 5) \mathrm{kg}$ nitrogen $(\mathrm{N}) / \mathrm{ha} / \mathrm{yr}$ in split applications throughout the season, and calving commenced on 9 July for both herds.

Only small differences between treatments in annual milksolids (MS) yield/cow were recorded. The Control herd averaged $310 \mathrm{~kg} \mathrm{MS} / \mathrm{cow}$ in 260 days compared with $316 \mathrm{~kg} \mathrm{MS} / \mathrm{cow}$ in 277 days for the HS Maize herd. The HS Maize herd produced 34\% more MS/ha than the Control herd, viz. 1566 and $1172 \mathrm{~kg} / \mathrm{ha} / \mathrm{yr}$ respectively.

Milksolids response to the additional DM and higher stocking rate (SR) on the HS Maize system averaged 80 g MS/kg extra DM consumed. The annual economic farm surplus (EFS) averaged over 4 years for the Control herd was \$2784/ha and the HS Maize herd was $\$ 2551 /$ ha, however greater between year variation in EFS was noted for the HS Maize system.

Incorporation of maize silage into a pasture-based dairy system does increase production/ha, however the profitability of the system will be more vulnerable to MS payout and maize silage price than the traditional pasture-based system.
\end{abstract}

Keywords: dairy, economic farm surplus, maize silage, pasture production

\section{Introduction}

The dairy industry has set a target to achieve a $4 \%$ productivity increase on an annual basis. Current thinking has it that management techniques have honed the New Zealand pasture-based dairy system to near its limit, and the only way to increase production is to use cost-effective feed inputs.

Previous research has shown that large MS responses can be achieved where extra feed is used to extend lactation length and fill feed deficits (Thomson et al. 1997; Penno et al. 1995, 1996). A response of $100 \mathrm{~g}$ MS/kg DM fed (reported by Penno et al. 1995; Pinares \& Holmes 1996) will return $\$ 0.40 / \mathrm{kg} \mathrm{DM}$ fed, at a payout of $\$ 4 / \mathrm{kg}$ MS. Therefore, it could be assumed that feed offered to the herd for less than $\$ 0.40 / \mathrm{kg}$ DM will generate a profit. Maize silage has been identified as a high quality feed source, which can be purchased and fed to the herd for less than $\$ 0.40 / \mathrm{kg}$ DM.

Milksolids responses of $100 \mathrm{~g} / \mathrm{kg}$ DM have been generated where large feed deficits are created by using very high SRs, 1 cow per hectare above the optimum on pasture only, and extending lactation by 30-60 days. These systems have used extra feed whenever pasture has been limiting DM intake/cow. This results in feed being used to fill spring, summer and autumn feed deficits. Clark (1993) showed that offering extra feed in spring, summer or autumn resulted in a similar total MS response/kg DM.

Thomson et al.(1991) reported a 10\% increase in MS production by shifting calving date 15 days earlier and using $\mathrm{N}$ fertiliser to supply extra early spring pasture. Simply moving calving date did not increase MS production. This demonstrates that where a system is already utilising available pasture, extra feed must be supplied to increase MS output.

The research reported in this paper was carried out to determine the profitability of farm systems using maize silage to increase total MS production by extending days-in-milk (DIM) and milking more cows per hectare.

\section{Materials and methods}

On 15 June 2000, two herds of 65 (Optimum Stocked (Control)) or 85 (High Stocked Maize (HS Maize)) Jersey cows were established at the Waimate West Demonstration Farm (WWDF), South Taranaki (Table 1). The herds were balanced for age, genetic merit, calving date and previous treatment. Comparative SR for the two herds was the same (Table 1). The Control

Table 1 Stocking rate, calving date and maize silage supplementation for the Control and HS Maize farmlets.

\begin{tabular}{lcc}
\hline & Control & HS Maize \\
\hline Cows & 65 & 85 \\
Area (ha) & 17.2 & 17.2 \\
SR (cows/ha) & 3.8 & 5.0 \\
$\begin{array}{l}\text { Comparative stocking rate } \\
\text { (kg LW/t DM available) }\end{array}$ & 85 & 84 \\
$\begin{array}{l}\text { Planned start of calving } \\
\text { Maximum maize silage available }\end{array}$ & 9 July & 9 July \\
(t DM/cow/yr) & 0 & 1.5 \\
\hline
\end{tabular}


Table 2 Farm expenses used for the calculation of EFS. Actual figures are indicated by an asterisk, all others are from the Dexcel Economic Survey of New Zealand Dairy Farmers 2003-04.

\begin{tabular}{|c|c|}
\hline \multicolumn{2}{|l|}{ Income } \\
\hline Milksolids @ actual milk price/kg (\$) & $3.63-5.30$ \\
\hline Net stock income (\$/cow) & 102 \\
\hline Expenses & \\
\hline Wages/ management allowance $(\$ / c o w)$ & 187 \\
\hline Animal health (\$/cow) & 57 \\
\hline Breeding and herd testing ( $\$ / \mathrm{cow})$ & 27 \\
\hline $\begin{array}{l}\text { Shed expenses ( } \$ / \text { cow } / 100 \text { DIM) } \\
\text { Electricity }(\$ / \text { cow } / 100 \text { DIM) }\end{array}$ & $\begin{array}{l}8.68 \\
8.68\end{array}$ \\
\hline Freight $(\$ /$ cow $)$ & 9.22 \\
\hline Silage harvesting costs ( $\$ /$ bale) & $25^{*}$ \\
\hline Silage bought ( $\$ /$ bale $)$ & $65^{*}$ \\
\hline Maize bought ( $\$ / \mathrm{kg}$ DM) & $0.25^{*}$ \\
\hline Wintering-off (\$/cow/week) & $15^{\star}$ \\
\hline Replacements (\$/cow) & 160 \\
\hline Fertiliser (\$/ha) & 200 \\
\hline $\mathrm{N}$ fertiliser $(\$ / \mathrm{kg})$ & 1.00 \\
\hline Weed \& pest $(\$ /$ ha $)$ & 17 \\
\hline Repairs and maintenance (\$/cow) & 77 \\
\hline Vehicles (\$/cow) & 48 \\
\hline Administration $(\$ /$ ha) & 70 \\
\hline Standing charges $(\$ / \mathrm{ha})$ & 194 \\
\hline Depreciation for both herds $(\$ / \mathrm{ha})$ & 215 \\
\hline Depreciation for HS herd only (\$/cow) & 19.32 \\
\hline
\end{tabular}

SR of 3.8 cows/ha was deemed to be the most appropriate for an all-grass system on the farm. It was based on results of 10 years previous research conducted on the farm under various SRs. Simulations using the UDDER model were used to determine the SR and level of maize silage supplementation for the HS Maize herd. During the season $20 \%$ of animals from both herds were culled and in May of each season the corresponding number of heifers was used to replace these animals. Heifers entering the herd were balanced for breeding worth (BW) and liveweight. The treatments remained the same and the trial was continued in the subsequent three years.

The Control farmlet was managed as a closed system however maize silage, winter grazing and a protein supplement if needed during summer were brought into the HS Maize system. Surplus pasture silage for each farmlet was carried forward into the next season. In the first year of the trial spoilage to the tube wrapped maize silage required the purchase of $460 \mathrm{~kg} \mathrm{DM} / \mathrm{cow}$ of pasture haylage for the HS Maize herd. The maximum level of maize silage available to the HS herd was $1.5 \mathrm{t}$ $\mathrm{DM} / \mathrm{cow} / \mathrm{yr}$. Maize silage was offered to ensure the intake of lactating cows did not fall below $12 \mathrm{~kg} \mathrm{DM} /$ cow/day. Daily levels of maize sila ge w ere calculated to ensure maize silage did not exceed $40 \%$ of the total diet.
Maize silage was ceased or reduced when lactating cows were offered more than $15 \mathrm{~kg} \mathrm{DM} / \mathrm{cow} /$ day as pasture. The maize was offered in trolleys on a stand-off area or in the paddock if soil and weather conditions allowed. From year two, 20 cows from the HS Maize herd were wintered off farm for eight weeks.

Cows were dried-off so that they reached the target calving condition score of $4.5-5$ by 1 June. Individual cows producing less than 51 /day for 2 consecutive weeks in late lactation (post-April) were dried-off and all cows were dried-off to ensure a 50-day interval between their last milking and their expected calving date. The timing of culling decisions was determined by feed supply following pregnancy diagnosis 8 weeks after the last mating. Culls were removed from the herd when DM intake of the herd fell below $8 \mathrm{~kg} / \mathrm{cow} /$ day.

Pasture mass was visually assessed in each paddock during a weekly farmwalk, and calibrated against actual mass cut from 12 quadrats (each $0.2 \mathrm{~m}^{2}$ ), six postgrazing and six pre-grazing. The quadrats were cut to ground level with an electric handpiece, washed and oven dried for 48 hours at $105^{\circ} \mathrm{C}$. The visual pasture mass assessments from each paddock were used to determine the rotation length and supplementary feed requirement. Cows were weighed and their condition score determined on a monthly basis. Milk from each herd was collected into separate vats and from daily factory records, milk yield and composition for each herd was obtained. Pre-mating heats were recorded for each cow from calving onwards, with tail paint used as an aid for heat detection. Detection of clinical mastitis was reliant on observations made by the farm manager. Individual somatic cell counts (SCC), milk fat and milk protein concentrations were determined from monthly herd testing.

An EFS was generated for both farmlets for each year of the trial. Because of the nature of the farm accounts many actual expenses could not be accurately apportioned to each herd, therefore in these instances the figures used have been based upon data collected by Dexcel (Economic Survey of New Zealand Dairy Farmers 2003-2004, Table 2). There has been no allowance made for extra staff in the HS Maize system as in some situations existing staff could be utilised to meet the demands of the increased workload from feeding the supplement. In the current trial, a very low labour system was implemented with the maize silage being fed in mobile trolleys. The EFS does not include provision for interest on capital, the purchase of additional shares/peak notes if required or for a feed pad for optimising maize silage feeding. However, a higher cost has been included for the HS Maize system for depreciation and the additional capital required for this system. 


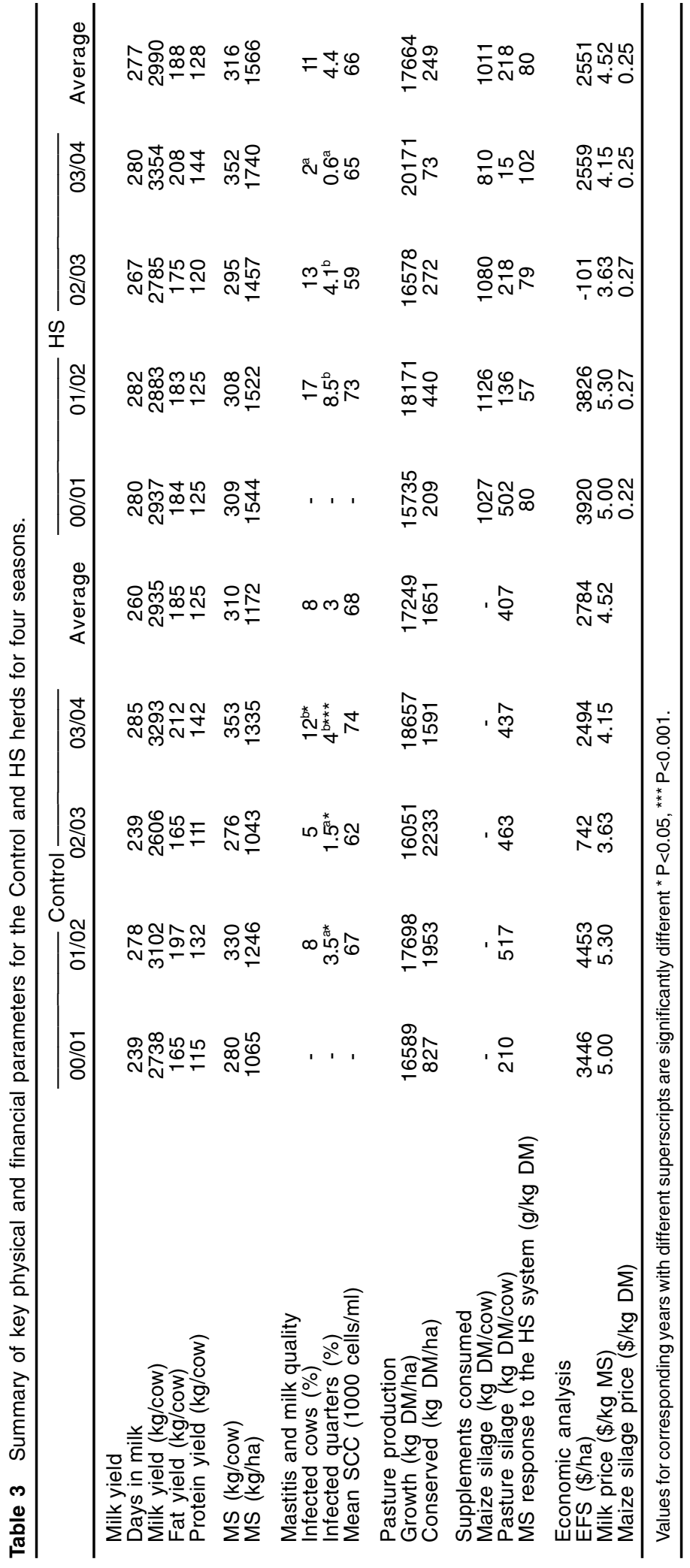

\section{Results}

Over the four years of the trial, there were only small differences between treatments in per cow milk yield, fat and protein yield (Table 3 ). The Control cows averaged $310 \mathrm{~kg} \mathrm{MS} /$ cow in 260 days compared with $316 \mathrm{~kg}$ $\mathrm{MS} /$ cow in 277 days for the HS herd. Because of the difference in stocking rate between the treatments the HS herd produced more MS/ha than the Control herd.

For the first three seasons, the HS herd had more cows with udder infections and a higher percentage of infected quarters, however, there were no differences in bulk milk SCC between treatments (Table 3).

Reproductive performance for the 2 herds was similar throughout the trial however there was considerable variation between seasons for both herds. Annual empty rates ranged from $0 \%$ to $15 \%$ for the HS Maize farmlet and $1 \%$ to $12 \%$ for the Control farmlet.

Monthly average pre- and postgrazing pasture mass values for each farmlet are presented in Table 4 . Pasture production was similar across the farmlets, however there was variation from year-to-year (Table 3). The major difference between the treatments was in the amount of pasture conserved as silage. The control herd conserved on average $1651 \mathrm{~kg} \mathrm{DM} /$ ha compared with only $249 \mathrm{~kg} \mathrm{DM} / \mathrm{ha}$ conserved on the HS farm. Pasture haylage was fed with the maize silage and pasture during the summer of 2001 to ensure the diet contained $16 \%$ crude protein.

The 2000/2001 year was noted for the drier conditions over summer with only $54 \%$ of the average rainfall for the December to April period while the 2002/2003 season experienced only $33 \%$ of the average rainfall for January and February.

Milksolids response to the additional DM provided and the higher SR on the HS Maize system ranged from 57 to $102 \mathrm{~g} / \mathrm{kg} \mathrm{DM}$. The highest response was observed in the 2003/ 2004 season when the requirement for 
Table 4 Mean $( \pm S E)$ monthly pre- and post-grazing pasture mass $(\mathrm{kg} \mathrm{DM} / \mathrm{ha})$ for the Control and HS Maize farmlets.

\begin{tabular}{|c|c|c|c|c|}
\hline & \multicolumn{2}{|c|}{ Control } & \multicolumn{2}{|c|}{ HS Maize } \\
\hline & Pre-grazing & Post-grazing & Pre-grazing & Post-grazing \\
\hline June & 3800 (39) & $1540(38)$ & $3860(9)$ & $1540(38)$ \\
\hline July & 3650 (48) & $1880(49)$ & 3720 (25) & $1870(47)$ \\
\hline August & $3730(105)$ & $1900(67)$ & 3540 (38) & 1860 (58) \\
\hline September & $3370(23)$ & 2150 (23) & $3480(168)$ & $2130(29)$ \\
\hline October & $3280(54)$ & $2200(5)$ & $3580(178)$ & $2180(19)$ \\
\hline November & $3390(63)$ & $2250(48)$ & $3480(189)$ & $2280(43)$ \\
\hline December & $3700(58)$ & $2430(159)$ & $3540(72)$ & $2420(161)$ \\
\hline January & $3750(100)$ & $2480(178)$ & 3540 (106) & 2490 (172) \\
\hline February & $3780(246)$ & $2550(136)$ & $3610(279)$ & $2570(156)$ \\
\hline March & $3760(135)$ & $2330(229)$ & $3670(145)$ & $2360(239)$ \\
\hline April & $3600(131)$ & $2180(242)$ & $2550(154)$ & $2160(244)$ \\
\hline May & $3700(40)$ & $1970(30)$ & $3730(92)$ & $2020(42)$ \\
\hline
\end{tabular}

Figure 1 Effect of milk price and maize silage price on EFS.

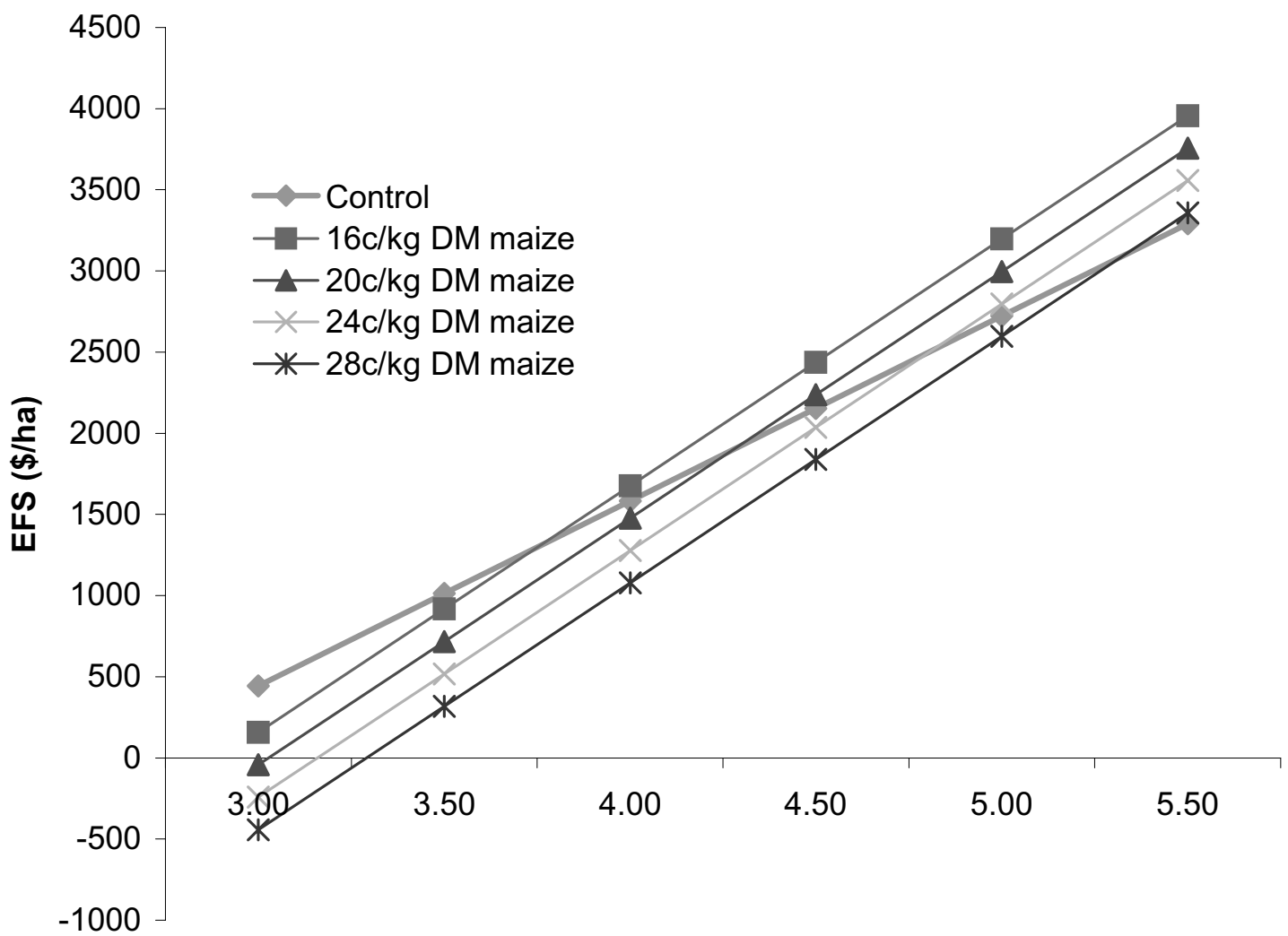

Milk price (\$)

maize silage supplementation was reduced because of excellent pasture growing conditions throughout the season. Record production was achieved for the farm in this season.

Economic analysis showed considerable variation between farm systems and betw een years (Table 3 ). The highest EFS of $\$ 4453 /$ ha was achieved by the Control herd in the 2001/2002 season while the lowest EFS of $\$ 101 /$ ha was achieved by the HS Maize herd in the 2002/ 2003 season. The impact of maize silage price and milk price has been calculated using average production and intake figures for the four years of the trial (Figure 1). 


\section{Discussion}

This trial has demonstrated that although efficient use of maize silage in a pasture-based system will increase production/ha, the profitability of the system will be dependent on a number of factors. Often increased production associated with high levels of supplementary feeding is offset by increased costs resulting in no increase in profit. The EFS of the HS Maize system was more vulnerable to variations in seasonal conditions, maize silage price and milk payout. By conducting the trial over four seasons we have observed variation in all of these factors. The first two seasons of the trial were high payout years ( $\$ 5.00$ and $\$ 5.30 / \mathrm{kg} \mathrm{MS}$, respectively) but these were followed by two years of low $(\$ 3.63 / \mathrm{kg} \mathrm{MS})$ and average $(\$ 4.15 / \mathrm{kg} \mathrm{MS})$ payout. During the $2000 /$ 2001 and 2002/2003 seasons, the region suffered drought conditions, which impacted on feed supply and therefore DIM, especially with the Control herd. What the economic analysis does show is that when a drought year coincides with a poor payout $(2002 / 2003)$ it is still possible to make money on an all-grass system. However, it is more difficult to make a profit with the HS maize system especially if you are paying more than $\$ 0.25 / \mathrm{kg}$ DM for maize and increased DIM cannot be achieved with supplementary feeding. Jensen et al. (2004) concluded that high input systems were more profitable and less affected by payout shift when maize silage could be purchased for $\$ 0.18 / \mathrm{kg}$ DM. The EFS for the Control farm in the current comparison ranged between $\$ 742$ and $\$ 4453 /$ ha compared with $-\$ 101$ to $\$ 3920 /$ ha for the HS maize system. Large profits can be made from the HS Maize system in high payout years if costs are contained, a finding supported by Jensen et al. (2004). Equally, high profits can be achieved from low input pasture-only systems under the same conditions.

Previous supplementary feeding research in NZ (Penno et al. 1996; Pinares \& Holmes 1996; Thomson et al. 1997) has demonstrated that the key to profitable supplementary feeding is to use the additional feed to increase lactation length. Maize silage supplementation in the current work increased days in milk on average by 17 days. While 17 days may at first glance appear inconsequential over the 4 years of the trial, it equates to an additional 397 lactation days/ha.

Milk production responses to supplementary feeding from previous research have ranged from 82-91 g MS/ $\mathrm{kg}$ DM maize grain (Penno et al. 1996) to $134 \mathrm{~g} \mathrm{MS} / \mathrm{kg}$ DM meal fed (Thomson et al. 1997). Average response in the current trial, $80 \mathrm{~g} \mathrm{MS} / \mathrm{kg}$ DM additional feed and increased SR, was similar to that reported by Penno et al. (1996). A key difference between previous work and the trial presented here is the absence of a true control in the current work. The HS Maize system incorporated both an increase in SR and maize silage supple- mentation. The higher response reported by Thomson $e t$ al. (1997) was attributed to the very early calving date (20 June) and the level of underfeeding experienced in early lactation. Thomson et al. (1997) concluded that high MS responses would only be achievable on commercial farms where constant pasture monitoring, feed planning and intensive pasture utilisation was practiced.

The amount of silage conserved on the HS farm was highest in the 2001/2002 season and declined steadily from there with only $73 \mathrm{~kg} \mathrm{DM} / \mathrm{ha}$ or $15 \mathrm{~kg} \mathrm{DM} / \mathrm{cow}$ being conserved in the final year of the trial. With this trend it would appear that the HS Maize system, over the four years, has become more effectively managed to utilise all the pasture grown without letting surpluses arrive and hence the need to make supplement.

The udder infection and SCC results in the current trial are supported by Lacy-Hulbert et al. (2002) who measured the incidence of mastitis in cows grazed on pasture or fed a total mixed ration (TMR) on a feed pad. More quarters of cows on TMR developed clinical mastitis compared with cows on grass. However, Lacy-Hulbert et al. (2002) also observed no differences in seasonal SCC between treatment groups. This was a reflection of the difference in types of pathogen predominantly causing mastitis. In the trial of Lacy-Hulbert et al. (2002) coliform mastitis frequently resulted in infected quarters in the TMR cows but only rarely caused sub-clinical mastitis, and in turn had a lessor effect on cow SCC (Lacy-Hulbert et al. 2002). The higher incidence of mastitis in the HS Maize could be explained by the increased exposure to environmental factors such as confinement of cows in a restricted area whilst consumption of maize is occurring.

\section{Conclusion}

This trial has demonstrated that incorporation of up to $22 \%$ of feed requirements as maize silage into a pasturebased system will increase production per hectare. However the profitability of the system will be more vulnerable to milk payout and maize silage price than the traditional pasture-based system. Farmers considering a higher stocked system need to ensure they have systems in place to maximize production and have risk management strategies in place to deal with years of high feed costs and/or low milk price.

\section{ACKNOWLEDGEMENTS}

The authors acknowledge the management and assistance given by the farm managers Alan and Joanne Mudgway and the support provided by the Waimate West Demonstration Farm Committee. Acknowledgement is also given to the technical assistance given by 
Claire Cooper and Maree Tong and the advice on mineral supplementation provided by John Roche. We thank Warwick Prewer for his advice on the financial analysis and Barbara Dow for statistical analysis of the data. MAF Sustainable Farming Fund and Fencepost provided financial support for the trial.

\section{REFERENCES}

Clark, D.A. 1993. Silage for milk production. Proceedings of the Ruakura Farmers 'Conference 45: 41-46.

Dexcel 2004. Economic survey of New Zealand dairy farmers 2003-2004.

Jensen, R.N.; Clark, D.A.; Macdonald, K.A. 2004. Dairying intensification; production responses and financial implications. Proceedings of the Agronomy Society of New Zealand 34: 13-20.

Lacy-Hulbert, S.J.; Kolver, E.; Williamson, J.H.; Napper, A.R. 2002. Incidence of mastitis among cows of different genotypes in differing nutritional environments. Proceedings of the New Zealand
Society of Animal Production 62: 24-29.

Pinares, C.; Holmes, C. 1996. Effects of feeding silage and extending lactation on the pastoral dairy system. Proceedings of the New Zealand Society of Animal Production 56: 239-244.

Penno, J.W.; Macdonald, K.W.; Bryant, A.M. 1996. The Economics of No. 2 Dairy Systems. Proceedings of the Ruakura Farmers 'Conference 48: 11-19.

Penno, J.W.; Thomson, N.A.; Bryant, A.M. 1995. Summer Milk - Supplementary Feeding. Proceedings of the Ruakura Farmers 'Conference 47: 17-24.

Thomson, N.A.; Hainsworth, R.; Clough, J.; McCallum, D. 1997. Effect of nitrogen fertiliser and concentrate feed on dairy production. Proceedings of the New Zealand Society of Animal Production 57: 172-174.

Thomson, N.A.; Roberts, A.; Judd, T.; Clough, J. 1991. Maximising dairy production by using nitrogen fertiliser and calving early. Proceedings of the New Zealand Grasslands Association 53: 85-90. 